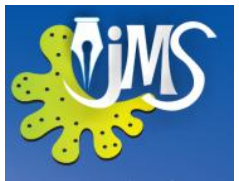

\title{
Drawbacks in SMEs' EIS Applications: Framework for Development of EIS for SMEs in Sri Lanka
}

\author{
I.R. Malawige ${ }^{1}$ and L.D.J.F. Nanayakkara ${ }^{2}$ \\ ${ }^{1}$ Department of Management of Technology, University of Moratuwa, Sri Lanka \\ ${ }^{2}$ Department of Industrial Management, University of Kelaniya, Sri Lanka
}

\begin{abstract}
The Small and Medium Scale Enterprises/Industries (SMEs) function as a lifeline in the informal sector in Sri Lanka due to their significant contribution to the overall economy in terms of employment, exports, innovation, tax income, equitable income distribution, social stability, domestic resources usage, and regional development. However, in Sri Lanka, a majority of Enterprise Information System (EIS) applications have not been focused by those 'small players' in the economy. The paper first identifies factors that contribute to SMEs relatively lower level of attraction towards EISs, using TOE Framework, which was tested mainly to assess the organization willingness on ICT in developing countries. Finally, the paper explains the ways and means by which the EIS vendors, SME and IT policy makers can address the gap between the current level and the potential for SME EIS adoption. Therefore the research findings help SMEs to create business opportunities with EIS applications and combat pressures from competition. Further specific SME ICT needs to be addressed strategically, in order to ensure their competitive position in the economy, will be discussed
\end{abstract}

KEYWORDS: SME, Enterprise Information Systems/EIS, Enterprise Resource Planning/ERP, TOE Framework, ICT Adoption. 


\section{INTRODUCTION}

Small and Medium- Sized Enterprises (SMEs) are of critical importance to many economies. In the Sri Lankan context more than 85 per cent of the industrial establishments are in small scale and medium scale and only 3 per cent are in large scale enterprises.

The general opinion is that the new technologies are not being used to their full potential and SMEs are principally focused on the accounts; furthermore the new technologies are seen as a cost rather than an investment and they are not trusted by SMEs.

The main objective of the research is to identify the factors that effect relatively lesser level of adoptability of Enterprise Information Systems (EIS) within the SME segment. Following objectives are to be undertaken as supplementary.

1. Identify and describe various factors that drop the focus of SMEs towards EIS

2. To provide full visibility on the EIS solutions to the SMEs expecting

The keystone of this effort is to find the reasons for the hesitation among Sri Lankan SMEs to move towards EIS. The framework that may effectively complement with the user needs and vendor capabilities of going ahead with better EIS solutions for SME segment will assist those EIS vendors in formulating product development and implementation strategies for Sri Lanka.

\subsection{Background / Literature Survey}

This section reviews prior research on SME segment, the context of EIS from a business angle, and the role of EIS in achieving a competitive advantage. Many studies have been conducted in order to establish influential factors, critical success factors, reasons for success and failure in EISs adoption and to provide guidelines to either assess readiness or to guide implementation in order to ensure a successful EIS adoption. However, less research has been conducted in Sri Lankan context in this regard.

\section{Small and Medium Enterprises (SMEs)}

SMEs play a central role in all most all economies with their contribution on promoting entrepreneurial skills, innovation, employment, investment/ growth and income generation.

In Sri Lanka, SMEs make up for more than 85 per cent of all businesses, and account for about 35 per cent of the employment and about 20 per cent of the total industrial value addition.

SMEs is considered as major economic players and as potential sources of national, regional and local economic growth (Taylor and Murphy, 2004). SMEs differ from large companies in important ways affecting their information-seeking practices (Buonanno et al., 2005). Thus, the adoption of EIS innovations in SMEs cannot be a miniaturized version of larger organizations.

The literature points out significant differences between SMEs and large organizations. The SME top management is usually involved in day-to-day activities (McCartan-Quinn and Carson, 2003). However, managers may have limited formal training (Lee and Oakes, 1995). Absence of long-term 
planning is another dominant factor (Gunasekaran et al., 1996). On the other hand, SMEs have relatively informal structures and culture (Mintzberg et al., 2003, p. 217), which increase cross-functional exchanges, and small management teams, which results in efficient decision making (Ghobadian and Gallear, 1996).

One major disadvantage of SMEs is lack of human and financial resources (Ghobadian and Gallear, 1996; Gunasekaran et al., 1996). Regarding IT, SMEs seldom have dedicated IT staff, let alone a formal department (Adam and O'Doherty, 2000; Mabert et al., 2000).

\section{Enterprise Information Systems (EIS)}

EIS is defined as "commercial software packages that enable the integration of transaction-oriented data and business processes throughout an organization and perhaps eventually throughout the entire interorganizational supply chain" (Markus and Tanis, 2000, p. 176).

Therefore, those systems provides a technology platform that enables organizations to integrate and coordinate their business processes, while ensuring that information can be shared across all functional levels and management hierarchies, serving the entire enterprise, or at least two functional departments.

Therefore, EIS can include enterprise resource planning (ERP), customer relationship management (CRM), supply chain management (SCM), and e-procurement systems (Shang and Seddon, 2002). Without a better understanding of the complex processes and differentiating factors that affect the adoption level of EIS innovations, the drive to adopt and develop IS innovations will not successfully contribute to SMEs' competitiveness (Martin and Matlay, 2001).

This type of software is a useful tool that businesses are turning to, in order to build strong capabilities, improve performance, undertake better decision-making, and achieve a competitive advantage.

Therefore these EIS applications, target any type of organization - corporations, partnerships, sole proprietorships, nonprofits, government agencies, and etc; targets both large and small organizations - Fortune 500 to 'Mom and Pop'; includes function-specific (Accounting, HR, Supply Chain, etc.) and industry-specific (Manufacturing, Retail, Healthcare, etc.) solutions.

\section{EIS implementation at SMEs}

Various researchers have recommended research into the implementation and use of EISs at SMEs (Huin et al., 2004; Mabert et al., 2003a;). Huin (2004, p. 516) argues that unless differences between small and large firms are understood, managing ERP projects in SMEs "..will continue to be slow, painful and at times even unfruitful". However, not many studies appear to have tackled this challenge yet.

The widely available researches on the arena include EIS/ICT innovation implementation, assessing the critical success factors and failures and impact analysis. However, it has been estimated that about half of EIS implementations fail to meet expectations. 
According to a review in the available literature, organizations adopting EIS certainly acquire benefits such as increase suppliers' and customers' satisfaction and an increase in productivity but the level of return on investment (ROI) is rather low. Findings of the previous research also suggest that many organizations adopting EIS have serious conflicts with their business strategies and the majority of EIS projects are often characterized by delays and cost overruns.

Combinations of factors have to be considered when undertaking an EIS implementation including: top management support, business plan and vision, Reengineering business process, effective project management and project champion, careful package selection process, teamwork and composition, user involvement and education and training (Premkumar and Roberts, 1999).

The critical success factors for EIS implementation include top management support, business plan and vision, business process reengineering, effective project management, teamwork and composition, system selection and user involvement and training (Markus \& Tanis, 2000)

\section{Research Models / Theories Adopted}

Following theoretical models have been used to examine SMEs' adoption of information systems and related innovations.

- Technology Acceptance Model (TAM) (Grandon and Pearson, 2004)

- Theory of Planned Behaviour (TPB) (Harrison et al., 1997)

- Combined TAM and TPB (Riemenschneider et al., 2003)
- Innovation diffusion theory (Premkumar, 2003)

- Resource-based view (Mehrtens et al., 2001)

- Unified Theory of Acceptance and Use of Technology (UTAUT) (Anderson and Schwager, 2004).

Tornatzky and Fleischer's TechnologyOrganization-Environment (TOE) framework (1990) has been tested and validated by many studies (e.g. Kuan and Chau, 2001; Premkumar and Roberts, 1999; Iacovou et al., 1995). This framework has also been claimed to be a generic theory of technology adoption/diffusion (Zhu et al., 2003) that can be used to study SMEs' adoption of EIS.

\section{MATERIALS AND METHODS}

The literature points out significant differences between SMEs and large organizations. SME top management is usually involved in day-today activities (McCartan-Quinn et al., 2003). However, managers may have limited formal training (Lee et al., 1995). Absence of longterm planning is another dominant factor (Gunasekaran et al., 1996).

On the other hand, SMEs have relatively informal structures and culture (Mintzberg et al., 2003) SMEs also differ from large companies in important ways affecting their information-seeking practices (Buonanno et al., 2005). Thus, the adoption of information systems (IS) innovations in SMEs cannot be a miniaturized version of larger organizations.

Many studies have been conducted in order to establish influential factors, critical success factors, reasons for success and failure EISs adoption and to provide guidelines to 
either assess readiness or to guide implementation in order to ensure a successful EIS adoption. However, less research has been conducted in Sri Lankan context in this regard.

The probable factors influencing EIS adoption by SMEs were identified through a literature review. Technology - Organization Environment (TOE) framework developed by Tornatzky and Fleischer (1990) has been used to identify the influential factors and test the validity in a Sri Lankan context.

TOE framework has been tested and validated by many studies (e.g. Iacovou et al., 1995; Kuan et al., 2001). TOE framework has also been claimed to be a generic theory of technology adoption/diffusion (Zhu et al., 2003) that can be used to study SMEs' willingness to adopt EIS.

A preliminary survey with participant companies that approximately reflect the population's statistical distribution in the industrial sectors, was conducted for initial exploratory intention. Based on preliminary survey findings on the subject matter four additional factors were added to the framework as shown in Table 1 (Factor No. 10, 11, 16, and 17) to be tested and verified using a case study approach. The weights associated with identified variables were also extracted through relevant literature and related research studies.
Table 1. Revised Framework on SME EIS Adoption Factors after Preliminary Survey

\begin{tabular}{|l|l|l|}
\hline $\begin{array}{c}\text { Technological } \\
\text { perspective }\end{array}$ & $\begin{array}{c}\text { Organizational } \\
\text { perspective }\end{array}$ & $\begin{array}{l}\text { Environmental } \\
\text { perspective }\end{array}$ \\
\hline $\begin{array}{c}\text { 1.Relative } \\
\text { advantage }\end{array}$ & 6.Size & 12.Industry \\
\hline 2.Compatibility & 7.IT Experience & $\begin{array}{l}\text { 13.Market } \\
\text { Scope }\end{array}$ \\
\hline 3. Complexity & $\begin{array}{l}\text { 8.Top } \\
\text { Management } \\
\text { Support }\end{array}$ & $\begin{array}{l}\text { 14.Competitive } \\
\text { Pressure }\end{array}$ \\
\hline $\begin{array}{l}\text { 4.Trail ability } \\
\text { 5.Observe } \\
\text { ability }\end{array}$ & $\begin{array}{l}\text { 10.Cultural } \\
\text { Readiness }\end{array}$ & $\begin{array}{l}\text { 15.External } \\
\text { ICT Support }\end{array}$ \\
\hline & $\begin{array}{l}\text { 11.Availability } \\
\text { and Economy } \\
\text { affordability of } \\
\text { growth } \\
\text { third party } \\
\text { support in } \\
\text { implementation }\end{array}$ & $\begin{array}{l}\text { 17.The } \\
\text { Government }\end{array}$ \\
\hline
\end{tabular}

For the purpose of this research however, the definition used by the white paper on the National Strategy for Small and Medium Enterprise Sector Development in Sri Lanka (2002) has been used with some amendments.

Table 2. SME Definition for Research Purpose

\begin{tabular}{|l|l|l|l|}
\cline { 2 - 4 } \multicolumn{1}{c|}{} & Small & Medium & \multicolumn{1}{c|}{ Large } \\
\hline $\begin{array}{l}\text { Number of } \\
\text { Employees }\end{array}$ & 29-May & $30-150$ & $\begin{array}{l}\text { More than } \\
150\end{array}$ \\
\hline $\begin{array}{l}\text { Annual } \\
\text { Revenue }\end{array}$ & $\begin{array}{l}\text { Less } \\
\text { than 10 } \\
\text { million } \\
\text { LKR }\end{array}$ & $\begin{array}{l}10-200 \\
\text { million } \\
\text { LKR }\end{array}$ & $\begin{array}{l}\text { More than } \\
\text { 200 million } \\
\text { LKR }\end{array}$ \\
\hline $\begin{array}{l}\text { By } \\
\begin{array}{l}\text { Investment } \\
\text { Excluding } \\
\text { land and } \\
\text { building) }\end{array}\end{array}$ & $\begin{array}{l}\text { Less } \\
\text { than 30 } \\
\text { million } \\
\text { LKR }\end{array}$ & $\begin{array}{l}35-100 \\
\text { million } \\
\text { LKR }\end{array}$ & $\begin{array}{l}\text { More than } \\
100 \text { million } \\
\text { LKR }\end{array}$ \\
\hline
\end{tabular}

This definition is based on the number of employees and the asset value excluding land and building. The definition has been amended 
mainly due to the fact that the above stated white paper has been published in 2002 and by now the inflation rate has increased thus changing the rupee value. The definition adopted is illustrated in Table 2.

The case study method was selected with its potential to accomplish analysis in depth; multiple respondents were targeted in organizations to ensure information richness and avoid possible biasness. The case study companies were selected considering the following characteristics (Refer Table 2 for company attributes).

- Have ensured the survival in the industry The necessity on IT of an emerging or ruining SME might not be high. Further it is assumed to be that only the 'fittest' SME will be survive after five years of establishment.

- Have interest on EISs or are knowledgeable about the ICT concepts - Most SMEs are either not aware or not willing to invest or participate in sophisticated technologies.

- Sri Lankan players in the industry - The real Sri Lanka context can be observed only through 'locally born' companies, as subsidiaries/branches of multi-national corporations are bound to follow the international standards and practice.

A questionnaire was used to validate the factors identified from the literature review. The questionnaires are intended to gather the following information.

- General Information (Organization name, Industry, No. of employees working)
- Open ended questions regarding basic factual information on the EISs and its implementation

- Statements to gather opinions on EIS based on a five point Likert scale

\section{RESULTS}

Hypothesis was developed to investigate the causes for relatively less adoption of EIS in SMEs in Sri Lanka.

$\mathrm{H}_{0}$ : The mean value of the population for a particular factor is less than or equal $3\left(\mu<=\mu_{0}\right)$

$\mathrm{H}_{1}$ : The mean value of the population for a particular factor is greater than $3\left(\mu>\mu_{0}\right)$

(Note: According to the likert scale used in the questionnaire, 3 represents "Neutral" level agreed level on the opinion)

Table 3. Summary of the attributes of the case study organizations

\begin{tabular}{|c|c|c|c|c|}
\hline Name & $\begin{array}{c}\text { Manufac } \\
\text { Co (Pvt) } \\
\text { Ltd. }\end{array}$ & $\begin{array}{c}\text { Manuf } \\
\text { acCo2 } \\
\text { (Pvt) } \\
\text { Ltd. }\end{array}$ & $\begin{array}{c}\text { HospitalCo } \\
\text { (Pvt) Ltd. }\end{array}$ & $\begin{array}{c}\text { HotelC } \\
\text { o (Pvt) } \\
\text { Ltd. }\end{array}$ \\
\hline $\begin{array}{l}\text { Industry } \\
\text { Sector }\end{array}$ & $\begin{array}{l}\text { Manufact } \\
\text { uring - } \\
\text { BOI } \\
\text { Company }\end{array}$ & $\begin{array}{l}\text { Manufa } \\
\text { cturing } \\
\text {-Export }\end{array}$ & Healthcare & Tourism \\
\hline $\begin{array}{l}\text { No. of } \\
\text { Employ } \\
\text { ees }\end{array}$ & Below 49 & $49-99$ & $49-99$ & $99-129$ \\
\hline $\begin{array}{l}\text { Annual } \\
\text { revenue } \\
\text { /Scale }\end{array}$ & $\begin{array}{l}\text { Rs } 100- \\
199 \mathrm{M} \\
\text { Medium }\end{array}$ & $\begin{array}{l}\text { Rs 50- } \\
99 \mathrm{M} \\
\text { Mediu } \\
\text { m }\end{array}$ & Medium & Medium \\
\hline $\begin{array}{l}\text { Nature } \\
\text { of the } \\
\text { EIS } \\
\text { Implem } \\
\text { entation }\end{array}$ & $\begin{array}{l}\text { ERP } \\
\text { Since } \\
\text { August } \\
2010\end{array}$ & $\begin{array}{l}\text { Micros } \\
\text { oft } \\
\text { Office } \\
\text { applicat } \\
\text { ions, } \\
\text { Accoun } \\
\text { ting } \\
\text { Packag } \\
\text { e }\end{array}$ & $\begin{array}{l}\text { Microsoft } \\
\text { Office } \\
\text { applications, } \\
\text { Quickbook, } \\
\text { Embeded } \\
\text { EIS } \\
\text { applications } \\
\text { in Medical } \\
\text { Equipments }\end{array}$ & $\begin{array}{l}\text { Tauras - } \\
\text { Reservat } \\
\text { ion and } \\
\text { Pay roll } \\
\text { system } \\
\text { (For } 5 \\
\text { years) }\end{array}$ \\
\hline
\end{tabular}

Note: Representative Company names have been used. 


\section{EVALUATION / DATA ANALYSIS}

The data set has been tested with Cronbach's Alpha for internal consistency before applying them for the analysis. For the results to be reliable, the variables have to obtain values greater than the cut off value of 0.7 as suggested by Nunnally (1978).

The values have been proved to be reliable and each of the three perspectives are essential for further analysis.

Cronbach's Alpha values

Organizational Perspective

Technological Perspective

Environmental Perspectives 0.948

The calculated $\mathrm{t}$ - values under each variable are greater than 1.833 (Degree of freedom-df $=9$; Level of significance $-\alpha=0.05$ ); and therefore $\mathrm{H}_{0}$ got rejected indicating that all the variables can be considered as applicable factors on EIS adoption in a Sri Lankan SME context, but with varying significance.

Problems in integrating with legacy systems, language barriers of staff, usability issues, problematic automated data tracking is due to the unavailability of timely data and limited company/industry specific versions have been identified as the limitations of the existing EIS applications.

The key considerations that drive organizations to choose the EIS vendor are product price, ability to provide a complete solution for client's needs, domain/industry specific knowledge, provision of tailor made solutions and support by means of staff training and subsequent up-grade.

Difficulties in estimating project requirements, technical difficulties in configuration, knowledge gap between implementers and users, lack of commitment from top leadership, significant resistance from managers, significant resistance from users/staff, turnover of key project persons, unavailability of skilled project people, high costs of implementation and lack of support and training from vendor are considered as the factors that affect the effectiveness of EIS.

However, the generalization of this reveals that 'SME EIS requirements' is relatively less accurate, due to the fact that the SMEs do not demonstrate the same level of IT adoption (in most cases the level of IT adoption among SMEs' is lower than the case study companies) as case study companies. 
Table 8. Statistical calculation on data set

\begin{tabular}{|c|c|c|c|c|c|}
\hline $\begin{array}{c}\text { Technique under each } \\
\text { tool }\end{array}$ & t-value & Standard Div. & Mean & $\begin{array}{c}\text { Coefficient } \\
\text { of variance } \\
(\%) \\
\end{array}$ & Rank \\
\hline \multicolumn{6}{|c|}{ Technological Perspective } \\
\hline Relative advantage & 49.49 & .241 & 4.645 & 5.20 & 1 \\
\hline Compatibility & 12.35 & 979 & 3.825 & 26.60 & 3 \\
\hline Complexity & 15.922 & .774 & 3.9 & 19.86 & 2 \\
\hline Trail ability & 10 & 0 & 4 & 0 & 4 \\
\hline Observability & 8.14 & .737 & 1.9 & 38.8 & 5 \\
\hline \multicolumn{6}{|c|}{ Organizational Perspective } \\
\hline Size & 19.092 & .298 & 1.8 & 16.56 & 5 \\
\hline IT experience & 6.427 & .897 & 1.825 & 49.2 & 4 \\
\hline $\begin{array}{l}\text { Top management } \\
\text { support }\end{array}$ & 20.023 & .663 & 4.2 & 15.79 & 3 \\
\hline $\begin{array}{l}\text { Organizational } \\
\text { Readiness }\end{array}$ & 18.97 & .668 & 4.01 & 16.66 & 2 \\
\hline Culture & 16.657 & .771 & 4.065 & 18.98 & 1 \\
\hline $\begin{array}{l}\text { Availability and } \\
\text { affordability of third } \\
\text { party support }\end{array}$ & 3 & 0 & 0.4 & 0 & 6 \\
\hline \multicolumn{6}{|c|}{ Environmental Perspectives } \\
\hline Market Scope & 10.614 & .774 & 2.6 & 29.79 & 3 \\
\hline Competitive pressure & 10.104 & 1.032 & 3.3 & 31.29 & 4 \\
\hline Extemal ICT support & 9 & 1.14 & 3.267 & 35.13 & 1 \\
\hline $\begin{array}{l}\text { Economy and } \\
\text { economic growth }\end{array}$ & 10 & 0 & 3 & 0 & 2 \\
\hline The Government & 39 & .158 & 1.95 & 8.1 & 5 \\
\hline
\end{tabular}

\section{CONCLUSION/FURTHER WORK}

\section{Conclusion}

Like any firm, an SME decides which type of EIS/ERP products to adopt based on the concrete benefits they can bring to its core business, the ICT capacity of its employees, capacity of its employees, and the financial resources available. In Sri Lankan context SMEs are familiar with basic ICT such as fixed phone lines, mobile phones, fax, computers, and basic document processing software - like Microsoft Office 


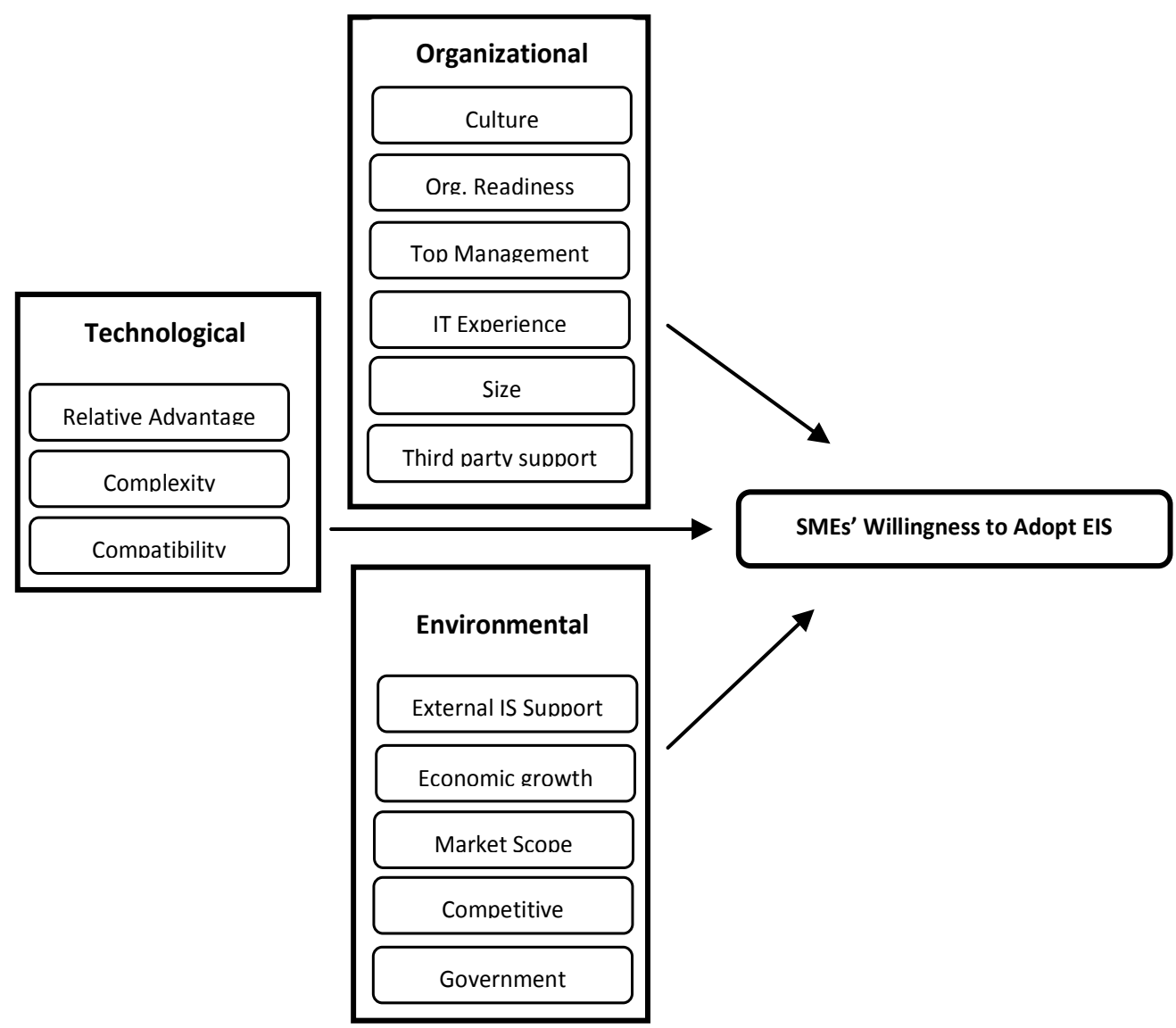

Figure 1. The factors mostly affecting SME EIS adoption in the Sri Lankan context

SMEs can benefit either as producers of ICT or as users of ICT for purposes such as increased productivity, faster communications and reaching new clients.

While ICT can benefit SMEs in multiple ways, SMEs have to identify their own obstacles in EIS adoption, considering their own business priorities and strategies. The major constraints being identified are level of initial investment, organizational culture, readiness, top management support, relative advantage, complexity, compatibility, the level of external IT support, economic and economic growth, and competitive pressure. To remove these constraints, governments need to do more than merely improve the ICT national policy and promote SMEs' ICT use/awareness.

The willingness of SMEs to integrate ebusiness practices depends on how much it can directly improve their core business and how much the potential benefits outweigh the definite costs. By recognizing these differences and focusing their efforts on removing the constraints, governments can play an important role in encouraging SMEs to become more effective users of EIS/ ERP. This can have wider impact on national economies since SMEs are the engines of economic growth. 


\section{Future Work}

The identification of factors that influence EIS adoption by local SMEs provide a gateway to new avenues of research.

- One such area to concentrate is the possible interrelationships between these factors. Relevant adoption factors can be assessed using a relatively large sample.

Novel findings can emerge through such studies. In-depth studies on individual factors may also lead to discovery of important research findings that will be beneficial to the local SME sector.

- The proposed Framework can be further validated before being used. It is recommended to be tested on a sufficient number of SME that have adopted EIS.

- Further research on post-implementation factors can be carried out to uncover factors that influence post-implementation success and can be assessed before system adoption. In that case post-implementation evaluation can also be included in the framework to further enhance its purpose.

\section{REFERENCES}

ADAM, F. AND O'DOHERTY, P. (2000). Lessons from enterprise resource planning implementations in Ireland - towards smaller and shorter ERP projects, Journal of Information Technology, Vol. 15 No. 4, pp. 305-16

ANDERSON, J.E. AND SCHWAGER, P.H. (2004). SMEs' adoption of wireless LAN technology: applying UTAUT model, Proceedings of the 7th Annual Conference of the Southern, Association for Information Systems, Savannah, GA, 17-28 February
BUONANNO, G., FAVERIO, P., PIGNI, F., RAVARINI, A., SCIUTO, D., TAGLIAVINI, M. (2005). Factors affecting ERP system adoption: a comparative analysis between SMEs and large companies. Vol. 18 No. 4, pp. 384426.Journal of Enterprise Information Management

GHOBADIAN, A. AND GALLEAR, D.N. (1996). Total quality management in SMEs, Omega, Vol. 24 No. 1, pp. 83-106

GRANDON, E.E. AND PEARSON, J.M. (2004). Electronic commerce adoption: an empirical study of small and medium US businesses, Information \& Management, Vol. 42 No. 1, pp. 197-216

GUNASEKARAN, A., OKKO, P., MARTIKAINEN, T. AND YLI-OLLI, P. (1996). Improving productivity and quality in small and medium enterprises: cases and analysis, International Small Business Journal, Vol. 15 No. 1, pp. 59-72

HARRISON, A.D., MYKYTYN, P.P. JR AND RIEMENSCHNEIDER, K.C. (1997). Executive decision about adoption of information technology in small business: theory and empirical tests, Information Systems Research, Vol. 8 No. 2, pp. 171-95

HUIN, S.F. (2004). Managing deployment of ERP systems in SMEs using multi-agents, International Journal of Project Management, Vol. 22 No. 6, pp. 511-17

IACOVOU, C., BENBASAT, I., DEXTER, A. (1995). Electronic Data Interchange and Small Organizations: Adoption and Impact of Technology. Vol. 19, pp 465-485.MIS Quarterly

KUAN, K. K. Y., CHAU, P. Y. K. (2001). A Perception-Based Model for

EDI Adoption in Small Business Using a Technology-Organization-Environment 
Framework. Vol. 38 pp. 507-512. Information and Management

LEE, G.L. AND OAKES, I. (1995). The 'pros' and 'cons' of total quality management for smaller firms in manufacturing: some experiences down the supply chain, Total Quality Management, Vol. 6 No. 4, pp. 41326

MABERT, V.A., SONI, A. AND VENKATARAMANAN, M.A. (2000). research on information technology implementation in small business, Journal of Organizational Computing and Electronic Commerce, Vol. 13, No. 2, pp. 91-121

PREMKUMAR, G. AND ROBERTS, M..(1999). Adoption of new information technologies in rural small businesses, Omega: The International Journal of Management Science, Vol. 27 No. 4, pp. 467-84

RIEMENSCHNEIDER, K.C., HARRISON, A.D. AND MYKYTYN, P.P. JR (2003).

Understanding IT adoption decisions in small business: integrating current theories, Information \& Management, Vol. 40 No. 4, pp. 269-85

SHANG, S. AND SEDDON, P.B. (2002). Assessing and managing the benefits of enterprise systems: the business manager's perspective, Information Systems Journal, Vol. 12 No. 4, pp. 271-99

TAYLOR, M. AND MURPHY, A. (2004). SMEs and e-business, Journal of Small Business and Enterprise Development, Vol. 11 No. 3, pp. 280-9.Z

TORNATZKY, L.G. AND FLEISCHER, M. (1990). The Process of Technological Innovation, Lexington Books, Lexington, MA

ZHU, K., KRAEMER, K.L., XU, S. (2003). Electronic business adoption by European firms: a cross-country assessment of the facilitators and inhibitors. Vol. 12 No. 4, pp. 251-68. European Journal of Information Systems

\section{ACKNOWLEDGMENT}

I would like to extend my sincere gratitude to the four case study companies and the co-author Dr. L.D.J.F.Nanayakkara. 